Check for updates

Montreal

Cite this as: $B M J 2021 ; 372: n 68$ http://dx.doi.org/10.1136/bmj.n68 Published: 08 January 2021

\section{Covid-19: WHO investigators are still blocked from entering China as two cities lock down}

\author{
Owen Dyer
}

A long awaited investigation led by the World Health Organization into the origins of the covid-19 pandemic remains on hold after scientists were unexpectedly refused entry to China at the last minute. At least two scientists were already travelling when WHO learnt that their visas had not been approved.

"I'm very disappointed with this news, given that two members have already begun their journeys, and others were not able to travel at the last minute," WHO’s director general, Tedros Adhanom Ghebreyesus, told reporters at a Geneva press conference on 5 January. "But I have been in contact with senior Chinese officials. And I have once again made it clear that the mission is a priority for WHO and the international team.”

A spokeswoman for China's foreign ministry later said at a Beijing press conference that there had been a "misunderstanding" and that China had not yet agreed on dates for the investigative visit or on its remit. Hua Chunying said, "The origins problem is very complex. To ensure that the work of the global experts group in China is successful, we need to carry out the necessary procedures and relevant concrete plans. Currently, both sides are still in negotiations on this."

She added, "I understand that it's not just a visa problem" but that it rather concerned "the actual date and itinerary." Later she told the BBC that there was "no need to read too much into" the delay. But a significant delay could prove a major public relations headache for China, feeding the narrative that it is concealing knowledge of the outbreak's origins.

\section{Severe new outbreak}

Last week Matthew Pottinger, US deputy national security adviser, told UK lawmakers at the Inter-Parliamentary Alliance on China that there was "a growing body of evidence to say that a laboratory leak or accident is very much a credible possibility."

"Even establishment figures in Beijing have openly dismissed the 'wet market' story," he added, pointing to the presence of the Wuhan Institute of Virology, where bat viruses were a focus of study. Pottinger has since resigned over the storming of the US Congress by supporters of Donald Trump.

China this week announced its most severe new outbreak in months, in the northern province of Hebei, which has seen 302 new cases in the past week. On 8 December authorities closed off the cities of Shijiazhuang and Xingtai, which together are home to about 18 million people, and began mass testing.

Small urban outbreaks in China have typically been met with lockdowns and massive testing drives. In October the port city of Qingdao tested more than 10 million people in four days after a dozen local cases were found. Days later, the prefecture of Kashgar in Xinjiang province locked down and tested nearly five million people after a single case appeared.

But reports from Hebei province suggested that surveillance had been lax in rural areas, allowing the virus to gain a stronger foothold than it has had in China for nearly a year. 